\title{
Puerto Rico: Sterile Breeding Grounds for Coercion and Uniformed Consent Susan G. Enberg
}

Susan Grace Enberg is currently completing her undergraduate degree. She has pursued majors in Peace, Conflict, and Justice Studies, and Latin American Studies. She has completed a minor in Caribbean Studies. Susan has focused intensely on human rights abuses committed by the U.S. and Canadian governments, abuses embedded in those countries' foreign policies. She received an honourable mention for her essay, "The Japanese Problem," on Japanese internment camps in Canada during World War II, and has been published as a G8 Civil Society Analyst. Her essay on the sixty-three year U.S. naval occupation of Vieques, Puerto Rico, was published in CARSSU's Caribbean Quilt 2012. Susan is pursuing graduate studies in documentary media and international human rights law.

"It is without being confuted that the degenerate blood of the country is controlled largely by the number of degenerate women; that in the lower strains of humanity the degenerate women reproduce to full natural capacity..."

-Harry H. Laughlin, Eugenical Sterilization in the United States

(pp. 440-441)

Puerto Rican women have consistently constituted the highest prevalence of sterilized women in the world. ${ }^{1}$ Many scholars question whether or not a negative eugenics campaign has been waged on the island by U.S. and Puerto Rican biomedical researchers, scientists, and public health officials in order to reduce and even potentially eliminate the Puerto Rican population, ${ }^{2}$ a

\footnotetext{
${ }^{1}$ Bonnie Mass, "Puerto Rico: A Case Study of Population Control," Latin American Perspectives, Issue 15, Vol. IV, No. 4 (Fall 1977):78.

2 Act 116 came into force as Law 136 on the island of Puerto Rico in May 1937 authorizing both state-sponsored and voluntary eugenic sterilization. Dorothy Roberts, Killing the Black Body: Race, Reproduction, and the Meaning of Liberty (New York: Vintage Books, 1997), 94; Jennifer A. Nelson, “'Abortions under Community Control': Feminism, Nationalism, and the Politics of Reproduction among New York City's Young Lords," Journal of Women's History, Vol. 13, No. 1 (Spring 2001): 168; Laura Briggs, Reproducing Empire: Race, Sex, Science, and U.S. Imperialism in Puerto Rico (California, U.S.A. Berkeley and Los Angeles, 2002), 123-128; Marsh J. Tyson Darling, “Eugenics Unbound: Race, Gender and Genetics" (presentation, Gender and Justice in the Gene Age: A Feminist Meeting on New Reproductive and Genetic Technologies, New York, U.S.A., May 6-7, 2004) : 6, accessed 15 February 2013,
} 
practice referred to by Mass as "birth genocide."3 By looking specifically at the bioethical issues of uninformed consent and coercion with respect to female reproductive sterilization, this essay will argue that Puerto Rican women's body sovereignty-the right of women to govern the physical borders of their own bodies-has indeed been violated in some instances, constituting a crime against humanity. Notably, it will be revealed that some Puerto Rican women suffered enforced or coerced tubal ligations, commonly known in Puerto Rico as "la operación," through a process of uniformed consent. Lastly, it will be argued that Puerto Rican women who have suffered reproductive abuses are not without avenues to redress. There are a great many conventions within the body of international laws that do offer sanctions against such abuse of women's reproductive capacities and thus could be utilized in the fight against sterilization abuse. Ultimately, a class action suit by Puerto Rican victims against those who have committed such abuses would provide litigation proceedings with greater clout, would have the potential to garner far greater international attention and support from other women's groups, and could also enhance women's collective sense of courageousness.

\section{Statistical Data on Rates of Female Sterilization in Puerto Rico}

According to a 2002 study by the organization Engender Health, "222 million women of reproductive age around the world are protected from unintended pregnancy by sterilization -180 million using female sterilization" and the highest incidences of female sterilizations currently occur in Latin America and the Caribbean. 5 The prevalence of women sterilized worldwide was highest in Puerto Rico at $45.2 \%$ as of $2002,{ }^{6}$ whereas the prevalence

http://www.gjga.org/inside.asp?action=item\&source=documents\&id=62\&detail $=$ print

3 Bonnie Mass, "Puerto Rico: A Case Study of Population Control," Latin American Perspectives, Issue 15, Vol. IV, No. 4 (Fall 1977): 79.

${ }^{4}$ La Operación, Videorecording, directed by Ana Maria García (1983; Puerto Rico: Latin American Film Project, 1983), DVD.

5Engender Health. "Sterilization Incidence and Prevalence"from Chapter 2 in Contraceptive Sterilization: Global Issues and Trends (2002): 17.

6lbid 30, 48. 
of male sterilization on the island is a mere $3.5 \% .7$ What this tells us is that in Puerto Rican society it is considered acceptable and even preferable to sterilize women and ultimately taboo to sterilize Puerto Rican men.

\section{Negative Eugenics}

Mass argues that female reproductive sterilization in twentieth-century Puerto Rico constituted a negative eugenics campaign, a racially-motivated program aimed at controlling and reducing unwanted births in a society. ${ }^{8}$ Citing Gordon (I974) and Chase (1977) in her article, "Puerto Rico: A Case Study of Population Control," she helps us to understand the basic insidious concept of negative eugenics:

Influenced by the Social Darwinists, significant members of the American ruling class developed theories of heredity which often concluded that the fittest in society be encouraged to breed selectively and that the "dysgenic," or less than fit, be weeded out so that the entire "human stock" be improved to the extent that the "aristogenic" individuals with perfect genes would abound. ${ }^{9}$

These beliefs became increasingly entrenched in the United States and "by 1930 laws against miscegenation had been enacted in 24 states, while 30 states as well as two Canadian provinces had laws calling for the sterilization of 'criminals,' the 'feeble-minded,' and the 'insane." "10 When looking back on history we find much solid evidence that racially-motivated negative eugenics campaigns were very active in the U.S., ${ }^{11}$ thus it is not unusual that scholars might

\footnotetext{
7lbid 31.

8Bonnie Mass, "Puerto Rico: A Case Study of Population Control," Latin American Perspectives, Issue 15, Vol. IV, No. 4 (Fall 1977): 67.

9lbid 66-67.

10 Bonnie Mass, "Puerto Rico: A Case Study of Population Control," Latin American Perspectives, Issue 15, Vol. IV, No. 4 (Fall 1977): 67; disturbingly, Laughlin lumps single mothers in with the insane, as they must be insane to consider raising a child without a man to support them: see Harry Hamilton Laughlin, Eugenical Sterilization in the United States (Chicago: Psychopathic Laboratory of the Municipal Court, December 1922).

${ }_{11}$ See generally Nancy Ordover, American Eugenics: Race, Queer Anatomy, and the Science of Nationalism (Minneapolis, Minnesota: University of Minnesota Press, 2003); Laura Briggs, Reproducing Empire: Race, Sex, Science, and U.S. Imperialism in Puerto Rico (California and London: University of California Press, 2002), 145-147. See also Harry Hamilton Laughlin, Eugenical Sterilization in the
} 
make the case that as a colony of the U.S., similar programs had been enacted in Puerto Rico. Indeed, in 1937 the Puerto Rican government followed the example of the mainland and passed Law $136^{12}$ to enact a eugenics program, inclusive of both state-directed and voluntary sterilization, as well as the establishment of a state-run sterilization board. ${ }^{13}$ Significantly, the law of sterilization was passed precisely when women's source of labor was deemed necessary to sustain the workforce. ${ }^{14}$ Puerto Rico was an island of sterile breeding grounds for coercion and uniformed consent with respect to female reproductive sterilization.

After atrocities committed by the Nazi scientific community came to international attention, negative eugenics campaigns were reframed by politicians and biomedical communities under the umbrella of Malthusian theory which "sold well on the mainland - it identified the cause of Third World poverty not as the history of colonialism but as ignorant women and too-large families, and it found the solution in suburban American-style domesticity and liberal democracy." ${ }^{5}$ However, Rodriquez-Trias makes an important ethical distinction between birth control and population control; she upholds that while birth control denotes choice and is reversible at will, population control is "more of a social policy instituted with the thought in mind that some people should not have children, or should have very few children." ${ }^{16}$ With this in mind, it becomes clear that negative eugenics campaigns are not entirely different from population control programs although the former denotes more coerciveness and insidiousness. While negative eugenics sought an ethnic or class-based cleansing of societies, population control

United States (Chicago: Psychopathic Laboratory of the Municipal Court, December 1922).

12La Operación, Videorecording, directed by Ana Maria García (1983; Puerto

Rico: Latin American Film Project, 1983), DVD.

13 Bonnie Mass, "Puerto Rico: A Case Study of Population Control," Latin

American Perspectives, Issue 15, Vol. IV, No. 4 (Fall 1977): 68; Johanna Schoen, Choice \& Coercion: Birth Control, Sterilization, and Abortion in Public Health and Welfare (Chapel Hill \& London: The University of North Carolina Press, 2005), 205.

${ }^{14}$ La Operación, Videorecording, directed by Ana Maria García (1983; Puerto Rico: Latin American Film Project, 1983), DVD.

${ }^{15}$ Laura Briggs, Reproducing Empire: Race, Sex, Science, and U.S. Imperialism in Puerto Rico (California and London: University of California Press, 2002), 147. ${ }^{16}$ La Operación, Videorecording, directed by Ana Maria García (1983; Puerto Rico: Latin American Film Project, 1983), DVD. 
programs after World War II were rhetorically packaged as essential for controlling the spread of Cold War communism and

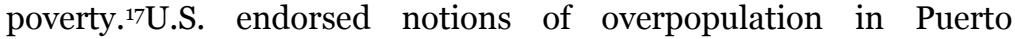
Ricomeant that population control initiatives were seen as a solution to both of these problems and thus garnered wide support from "government officials, teachers, newspaper editors, social workers, nurses, hospital administrators and some physicians...who relentlessly promoted birth control, surgical sterilization, and small families." 18

\section{Women Workers Needed: Operation Bootstrap}

In addition, demands for more industrial workers at the onset of Operation Bootstrap helped to promote issues of controlled family size, as many of Bootstrap's workers were Puerto Rican women.19Cordero-Guzman adds particular clarity by stating "Bootstrap's pillars were low wages, the lack of trade barriers between the island and the mainland, a policy of population control, ${ }^{20}$ and Section 936 of the U.S. Federal Tax code, which leaves relatively untaxed the profits earned by Puerto Rican subsidiaries of U.S. companies. ${ }^{21}$ Thus, U.S. foreign policy can be directly tied to women's reproductive agency and state measures at population control in Puerto Rico.

Unquestioningly, the overall socio-economic and physical health of Puerto Ricans suffered due to the exploitive tendency of the U.S. administration and investors that overtook massive tracts of rural lands, critical to the very survival of traditional Puerto Rican agriculturalists, in order to establish capital intensive heavy industries which employed relatively few ${ }^{22}$ therefore "creating an excess population." ${ }^{33}$ However, as early as the 1930 s the U.S. blamed

\footnotetext{
17Laura Briggs, Reproducing Empire: Race, Sex, Science, and U.S. Imperialism in Puerto Rico (California and London: University of California Press, 2002), 112.

18lbid 122.

19lbid 122.

${ }^{20}$ My emphasis.

${ }^{21}$ Hector R. Cordero-Guzman, "Lessons from Operation Bootstrap," NACLA

Report on the Americas, Vol. 27, Issue 3 (November-December 1993): 1.

${ }_{22}^{2}$ Manos a la Obra, Videorecording, directed by Susan Zeig and Pedro Angel

Rivera and Cinema Guild (1983: City University of New York and Centro de

EstudiosPuertorriqueños, 2005), videorecording.

${ }^{23}$ La Operación, Videorecording, directed by Ana Maria García (1983; Puerto

Rico: Latin American Film Project, 1983), DVD.
} 
overpopulation for Puerto Rican poverty and denied any culpability. "Clearly omitted from defense of an official birth reduction policy was the economic situation of a colonized economy based on the extraction of resources which increasingly turned Puerto Rico's working population into a marginal and surplus labor force." 24 Yet many of the industries created under Operation Bootstrap subsequently uprooted from Puerto Rico during a period of high inflation in the mid-1970s, leaving many Puerto Rican islanders bereft of the means to support their families. ${ }^{25}$ A great number of Puerto Rican women had been sterilized to serve the needs of industry in Puerto Rico, and their wombs too were now bereft.

What must be understood is that the U.S. controlled Puerto Rican government, Puerto Rican elites, and the Puerto Rican biomedical community had vested interests to become a more 'progressive' society like their colonizer to the north. These groups sought to control population growth by transgressing the sovereign borders of Puerto Rican women's reproductive capacities. One consequence was that women's bodies were at times abused to meet the dual goals of improving the socio-economic lot of the Puerto Rican people and of absolving U.S. corporate interests for the part they played in creating depressed socio-economic conditions on the island. Women's wombs were to be controlled if Puerto Rico's socioeconomic situation was to improve. The question was whether or not Puerto Rican women were perceived as capable of controlling their own sites of reproduction.

\section{Racial Derogation of Puerto Rican Women}

Derogatory notions of women were prevalent in the U.S. in the early twentieth century. Johnson for one wrote, "Women physically, they are only babies in intellect and self-control. We say

\footnotetext{
24Bonnie Mass, "Puerto Rico: A Case Study of Population Control," Latin American Perspectives, Issue 15, Vol. IV, No. 4 (Fall 1977): 69.

${ }^{25}$ Manos a la Obra, Videorecording, directed by Susan Zeig and Pedro Angel Rivera and Cinema Guild (1983: City University of New York and Centro de EstudiosPuertorriqueños, 2005), videorecording; Bonnie Mass, "Puerto Rico: A Case Study of Population Control," Latin American Perspectives, Issue 15, Vol. IV, No. 4 (Fall 1977): 69-70, 73; La Operación, Videorecording, directed by Ana Maria García (1983; Puerto Rico: Latin American Film Project, 1983), DVD.
} 
to these children 'You shall be virtuous or you will be damned," 26 while Ordover upholds that the sterilization of women can be seen as a "punitive measure" meant to punish "poor people of color (who) cannot be trusted to regulate their own fertility." ${ }^{27}$ With regard to Puerto Ricans, Nelson shares how "in 1932...Cornelius Rhoads, a U.S. physician who worked in the San Juan Presbyterian Hospital under a Rockefeller Foundation grant, advocated the elimination of Puerto Ricans in a private letter" 28 that was subsequently leaked then published. ${ }^{29}$ To add fuel to the fire, the U.S. appointed governor of Puerto Rico, James R. Beverley, stated that, "the problem was not merely the quantity but also the quality of the Puerto Rican population." 30 These derogatory and racist notions of Puerto Ricans were prevalent within biomedical institutions in both the U.S. and in Puerto Rico and became embedded in institutional policies.

Mass cites Presser (1973: 38) who states that "the Joint Committee for Hospital Accreditation...refused recognition to Puerto Rico's hospitals unless a ten percent limit of sterilization (in proportion to all hospital deliveries) was agreed upon." ${ }^{31}$ Such policies provided an unethical opening in the Puerto Rican biomedical field that resulted in a great number of coerced sterilizations of Puerto Rican women authorized through processes of obtaining uninformed consent. The derogation of Puerto Rican women as being unable or unwilling to make sound decisions concerning their own body sovereignty, as well as violations of this sovereignty through biomedical practices of coercion and of obtaining what I have called uninformed consent to enforce female sterilization are highly disturbing.

\footnotetext{
${ }^{26}$ Alexander Johnson, "Race Improvement by Control of Defectives (Negative Eugenics)," Annals of the American Academy of Political and Social Science, Vol. 34, No. 1, Race Improvement in the United States (July 1909): 27-29. According to Johnson "feeble-minded" women were often those who gave birth out of wedlock and subsequently considered to be "habitual tramps".

${ }^{27}$ Nancy Ordover, American Eugenics: Race, Queer Anatomy, and the Science of Nationalism (Minneapolis, Minnesota: University of Minnesota Press, 2003),

133.

28Jennifer A. Nelson, “'Abortions under Community Control': Feminism, Nationalism, and the Politics of Reproduction among New York City's Young Lords," Journal of Women's History, Vol. 13, No. 1 (Spring 2001): 168.

29lbid 168.

30lbid 168.

31 Bonnie Mass, "Puerto Rico: A Case Study of Population Control," Latin American Perspectives, Issue 15, Vol. IV, No. 4 (Fall 1977): 73.
} 
Uniformed consent can include (but is not limited to) medical practitioners failing to divulge the full scope of what will happen during a tubal ligation procedure, failing to divulge whether or not the procedure will be reversible, neglecting to ask women if they would like to have the procedure done but rather asking the question to the women's husbands, asking women to sign forms under duress or while medicated, using coercive measures such as telling women that they must be sterilized before the hospital will agree to admit them to a maternity ward, that women will be denied welfare payments unless they agree to sterilization, and most insidiously, performing the surgery without telling women at all. $3^{2}$

\section{U.S. Concerns over Population Growth and USAID to Stem the Growth}

In 1966, the U.S. government began to send funding to Puerto Rico for their family planning programs, 33 and "from 1968 to 1972 USAID increased its budget for birth control to Latin America to $\$ 100$ million, however it reduced sorely needed healthcare assistance by the same amount."34Jumping forward to 1974, U.S. foreign policymakers were greatly concerned that "population or growth imbalances will produce disruptive foreign policies and international instability," and that slow development in poorer countries would hinder U.S. economic aspirations while, at the same time, would require U.S. food aid. Notably, the U.S. government had hoped to discover whether technological innovations could help to "ameliorate" the effects of population growth. ${ }^{35 W e}$ might assume

\footnotetext{
${ }^{32}$ See generally, Bonnie Mass, "Puerto Rico: A Case Study of Population Control," Latin American Perspectives, Issue 15, Vol. IV, No. 4 (Fall 1977); and La Operación, Videorecording, directed by Ana Maria García (1983; Puerto Rico: Latin American Film Project, 1983), DVD; and Johanna Schoen, Choice \& Coercion: Birth Control, Sterilization, and Abortion in Public Health and Welfare (Chapel Hill \& London: The University of North Carolina Press, 2005).

${ }^{33}$ Aaron Segal with the assistance of Kent C. Earnhardt. Politics and Population in the Caribbean: Special Study No. 7. Rio Piedras, Puerto Rico: Institute of Caribbean Studies, University of Puerto Rico, 1969: 109.

${ }^{34}$ La Operación, Videorecording, directed by Ana Maria García (1983; Puerto Rico: Latin American Film Project, 1983), DVD.

${ }^{35}$ Henry A. KissInger, "National Security Study Memorandum 200: Implications of Worldwide Population Growth for U.S. Security and Overseas Interests" (Memorandum, Washington, D.C., 1974), accessed 15 December 2012,
} 
that these 'technological innovations' in part refer to reproductive sterilization and other methods of birth control. ${ }^{36}$

\section{Coerced Sterilization, Uniformed Consent, and La Operación}

According to the Chicago Committee to End Sterilization Abuse (CESA), "probably one of the most insidious U.S. population control programs in the Third World has been in Puerto Rico, which has the highest incidence of sterilization in the world." ${ }^{37}$ Schoen states that "with the inclusion of sterilization in federally funded family planning programs in the late 1960 s, it not only became significantly easier for health and welfare officials to make sterilization available as a form of permanent birth control, it also became much easier to coerce women into accepting sterilizations they might not have chosen on their own."38Thus U.S. federal funding toward female sterilization can be seen as a coercive means to a calculating end: to control the number of births of Puerto Ricans in Puerto Rico.

Mass articulates that, "During the late 1930s, fifty-three clinics opened, and sterilization, labeled 'la operación,' was used as the major means of controlling Puerto Rico's population growth." ${ }^{9}$ Ana María García's film, La Operación, sheds critical light on the issue of Puerto Rico as a laboratory of the U.S. with respect to the development of birth control methods. ${ }^{\circ}$ Notably, García provides

\footnotetext{
http://www.druckversion.studien-vonzeitfragen.net/NSSM\%20200\%20Executive\%20Summary.htm 36 My note.

${ }^{37}$ The Chicago Committee to End Sterilization Abuse, "Sterilization Abuse: A Task for the Women's Movement," The CWLU Herstory Website Archive (1977), accessed 28 March 2013, https://www.uic.edu/orgs/cwluherstory/CWLUArchive/cesa.html 38Johanna Schoen, Choice \& Coercion: Birth Control, Sterilization, and Abortion in Public Health and Welfare (Chapel Hill \& London: The University of North Carolina Press, 2005), 215; The Chicago Committee to End Sterilization Abuse, "Sterilization Abuse: A Task for the Women's Movement," The CWLU Herstory Website Archive (1977), accessed 28 March 2013, https://www.uic.edu/orgs/cwluherstory/CWLUArchive/cesa.html 39Bonnie Mass, "Puerto Rico: A Case Study of Population Control," Latin American Perspectives, Issue 15, Vol. IV, No. 4 (Fall 1977): 69. ${ }^{40}$ La Operación, Videorecording, directed by Ana Maria García (1983; Puerto Rico: Latin American Film Project, 1983), DVD.
} 
concrete examples of coerced female sterilization and uniformed consent in Puerto Rican society by enabling the voices of affected Puerto Rican women. The documentary brings to light how many Puerto Rican women could not afford nor easily obtain non-surgical birth control methods when they became commercially available, how some were offered sterilization as the only method of birth control, or were told by medical practitioners that having more children would be dangerous to their health. Thus many women opted for tubal ligations, offered for free in a hospital setting (due to the federal funding mentioned above), or for a one-time fee at private clinics. ${ }^{41}$ Pressuring women's reproductive agency even further, husbands were told by medical practitioners that vasectomies were not reversible. Puerto Rican men were also concerned that they might become sexually dysfunctional if sterilized. ${ }^{42}$ Thus male resistance to the procedure directly or indirectly pressured their female partners to have the operation.

Many of the women portrayed in Garcia's film attest to choosing sterilization because of their impoverishment. With respect to this, Søren Holm in Häyrey et al. states that, "In extreme poverty it is not the case that you cannot get your wants satisfied; it is the case that you have no legitimate way of satisfying those basic organic survival needs. If you want to go on living you have to do something." 43 As Puerto Rican women both desired and felt pressured to control family size, sterilization in the absence of other safe, affordable, and easily accessible options seemed a pragmatic choice. However we must provide thoughtful consideration to Holm's words of wisdom: "Being poor means that you are likely to accept offers that people who are not poor would not accept, and this raises the issue of whether being poor leaves you open to exploitation, whether we can say poverty coerces..." 44

La Operación provides testimonials from women who were told by medical practitioners that their tubes would be tied-a procedure perceived as reversible by many women-however some of

${ }^{41}$ lbid.

42Ibid.

43Søren Holm, "Is Bioethics Only for the Rich and Powerful?" in MattiHäyry and TuijaTakala and Peter Herissone-Kelly and GardarÁrnason, eds.,Arguments and Analysis of Bioethics, Vol. 214(Amsterdam, New York, NY: Value Inquiry Books Series, 2010), 32.

${ }^{44}$ Ibid 24. 
these women discovered after the surgical procedure that their fallopian tubes had been tied and cut rendering them permanently sterile.45Many other Puerto Rican women were coerced into signing consent forms under duress - in the absence of their husbands, while in labour, or immediately after giving birth. ${ }^{46}$ This practice clearly constitutes what I have called uniformed consent, and given the circumstances under which consent forms were signed must be seen as both coercive and enforced.

Institutionally, some Puerto Rican hospitals had policies that either formally or informally mandated doctors to pressure mothers who had just given birth to have tubal ligations, 47 while some had policies to turn women away from the maternity ward unless they agreed to sterilization after giving birth.48In 1947, at the Presbyterian Hospital, it was an unofficial policy "to turn away women in labour for their fourth delivery unless they agreed to sterilization." ${ }^{49 H o w e v e r, ~ B r i g g s ~ r e i n f o r c e s ~ t h e ~ n o t i o n ~ t h a t ~ t o ~ b e ~}$ medically unethical is a judgment call to be made by the biomedical community alone, despite the repercussions suffered by victims of such practices. It is precisely this type of apathy that reinforces the authority of governments and medical communities that implicitly or in complicity support and commit such reproductive abuses.

\section{Conclusions}

This author has not found enough evidence in the form of primary documents to support the argument that a systematic negative eugenics program was launched against the population of Puerto Rico with an objective of racial genocide. However, eugenic thought and rhetoric abounded for much of the twentieth century, as did systematic population control policies aimed specifically at women's bodies in Puerto Rico. Puerto Rican women's bodies were deemed as the sites of reproduction to be controlled, ${ }^{50} \mathrm{a}$ Western

\footnotetext{
${ }^{45}$ La Operación, Videorecording, directed by Ana Maria García (1983; Puerto Rico: Latin American Film Project, 1983), DVD. My emphasis in italics.

${ }^{46}$ lbid.

47Laura Briggs, Reproducing Empire: Race, Sex, Science, and U.S. Imperialism in Puerto Rico (California and London: University of California Press, 2002), 157. 48lbid 158.

49 lbid 157.

50Johanna Schoen, Choice \& Coercion: Birth Control, Sterilization, and Abortion in Public Health and Welfare (Chapel Hill \& London: The University of North Carolina Press, 2005), 201. My emphasis in italics.
} 
notion that was insidiously reinforced in the pages of Puerto Rican textbooks. ${ }^{51}$ Population control policies consequently opened the door for unethical practices and abuses by the medical community especially once USAID affirmed that they would economically compensate Puerto Rican physicians for sterilization procedures of Puerto Rican women. Limited options for safe, affordable birth control in Puerto Rico throughout the twentieth century must also be considered. With choices constrained, it is not unusual that Puerto Rican women often chose reproductive sterilization. The tragedy is that Puerto Rican women often believed that they could have their tubes untied in the future should they desire to have more children.

In cases of reproductive abuse, Puerto Rican women can turn to the body of international laws such as the Convention on the Elimination of All Forms of Discrimination against Women,52the American Convention on Human Rights, 53 Article 12 of the Universal Declaration for Human Rights, 54 the Covenant for Civil and Political Rights, 55 the United Nations Declaration on the Rights of Indigenous Peoples, ${ }^{6}$ the International Covenant on Economic, Social and Cultural Rights,57 the Beijing Declaration and Platform for Action, ${ }^{8}$ and lastly, the Convention on the Prevention and Punishment of the Crime of Genocide 59 in the event that the burden of proof can show without doubt that an insidious negative-eugenics campaign was waged against the peoples of Puerto Rico.

\footnotetext{
51La Operación, Videorecording, directed by Ana Maria García (1983; Puerto Rico: Latin American Film Project, 1983), DVD.

${ }^{52}$ Kelsey Collier-Wise, "Bearing Witness: Looking for Remedies for Forced Sterilization of Indigenous Women," Law Students for Reproductive Justice, p. 16, accessed 28 March 2013, http://lsrj.org/documents/awardsgrants/CollierWise_Forced-Sterilization_Indigenous_Women.pdf

53lbid 18.

54Ibid 19.

${ }^{55}$ Kelsey Collier-Wise, "Bearing Witness: Looking for Remedies for Forced Sterilization of Indigenous Women," Law Students for Reproductive Justice, p. 18, accessed 28 March 2013, http://Isri.org/documents/awardsgrants/CollierWise_Forced-Sterilization_Indigenous_Women.pdf

56 Ibid 19-20

57lbid 20.

58|bid 20.

59lbid 19.
} 
Notably, legal precedence against enforced sterilization of women has been set by Peru through the Inter-American Commission for Human Rights (IACHR). ${ }^{60}$ To this end, I would recommend that Puerto Rican women who have become victims of coercive or enforced sterilization join forces with other women's organizations around the world that have solid experience in such litigation, such as women from the Chicago Women's Liberation Union. ${ }^{61}$ Indeed, Puerto Rican women have every right to have their voices heard in an international legal environment such as the IACHR. In addition, there is substantial reasonto seek justice for the bioethical transgressions of women's bodies through the processes of coercion and uniformed consent that have resulted in permanent sterility. It is imperative for women to remember that those who fight for their rights today help to ensure future protections for women around the world. With respect to reinforcing women's rights and body sovereignty, legal precedence accounts for much. Ordover questions, "Who has paid, and who will continue to pay, the physical and political consequences of these configurations?"62 Women's must answer, 'Not Us!'

60 Organization of American States, "Inter-American Commission for Human Rights," accessed 28 March 2013, http://search.oas.org/en/iachr/default.aspx?k=sterilization\&s=CIDH

${ }^{61}$ The Chicago Committee to End Sterilization Abuse, "Sterilization Abuse: A Task for the Women's Movement," The CWLU Herstory Website Archive (1977), accessed 28 March 2013, https://www.uic.edu/orgs/cwluherstory/CWLUArchive/cesa.html 62Nancy Ordover, American Eugenics: Race, Queer Anatomy, and the Science of Nationalism (Minneapolis, Minnesota: University of Minnesota Press, 2003), 215. 


\section{Work Cited}

Briggs, Laura. Reproducing Empire: Race, Sex, Science, and U.S. Imperialism in Puerto Rico. California and London: University of California Press, 2002.

Chicago Committee to End Sterilization Abuse (The), "Sterilization Abuse: A Task for the Women's Movement," The CWLU Herstory Website Archive (1977).Accessed28March2013.https://www.uic.edu/orgs/cwluherstory/CW LUArchive/cesa.html

Cordero-Guzman, Hector R."Lessons from Operation Bootstrap." NACLA Report on the Americas, Vol. 27, Issue 3 (November-December 1993).

Darling, Marsh J. Tyson "Eugenics Unbound: Race, Gender and Genetics" (presentation, Gender and Justice in the Gene Age: A Feminist Meeting on New Reproductive and Genetic Technologies, New York, U.S.A., May 6-7, 2004). Accessed 15 February 2013.

http://www.giga.org/inside.asp?action=item \&source=documents $\& i d=62 \& d$ etail=print

Engender Health. "Sterilization Incidence and Prevalence" from Chapter 2 in Contraceptive Sterilization: Global Issues and Trends (2002): pp. 17-48.

Holm, Søren. "Is Bioethics Only for the Rich and Powerful?" in MattiHäyry and TuijaTakala and Peter Herissone-Kelly and GardarÁrnason, eds. Arguments and Analysis of Bioethics, Vol. 214.Amsterdam, New York, NY: Value Inquiry Books Series, 2010, pp. 23-35.

Johnson, Alexander. "Race Improvement by Control of Defectives (Negative Eugenics)," Annals of the American Academy of Political and Social Science, Vol. 34, No. 1, Race Improvement in the United States (July 1909): 22-29.

Kelsey Collier-Wise. "Bearing Witness: Looking for Remedies for Forced Sterilization of Indigenous Women." Law Students for Reproductive Justice. Accessed 28 March 2013.

http://Isri.org/documents/awardsgrants/Collier-Wise_Forced-

Sterilization Indigenous Women.pdf

Kissinger, Henry A. "National Security Study Memorandum 200: Implications of Worldwide Population Growth for U.S. Security and Overseas Interests." Memorandum, Washington, D.C., 1974. Accessed 15 December 2012. http://www.druckversion.studien-von-

zeitfragen.net/NSSM\%20200\%20Executive\%20Summary.htm 
La Operación, Videorecording. Directed by Ana Maria García. 1983. Puerto Rico: Latin American Film Project, 1983: DVD.

Laughlin, Harry Hamilton. Eugenical Sterilization in the United States. Chicago: Psychopathic Laboratory of the Municipal Court, December 1922.

Manos a la Obra. Videorecording. Directed by Susan Zeig and Pedro Angel Rivera and Cinema Guild. 1983. City University of New York and Centro de Estudios Puertorriqueños, 2005: Video recording.

Mass, Bonnie. "Puerto Rico: A Case Study of Population Control," Latin American Perspectives, Issue 15, Vol. IV, No. 4 (Fall 1977): 66-82.

Nelson, Jennifer A. “'Abortions under Community Control': Feminism, Nationalism, and the Politics of Reproduction among New York City's Young Lords," Journal of Women's History, Vol. 13, No. 1 (Spring 2001): 157-180.

Ordover, Nancy. American Eugenics: Race, Queer Anatomy, and the Science of Nationalism. Minneapolis, Minnesota: University of Minnesota Press, 2003.

Organization of American States, "Inter-American Commission for Human Rights," accessed 28 March 2013.

http://search.oas.org/en/iachr/default.aspx?k=sterilization\&s=CIDH

Roberts, Dorothy. Killing the Black Body: Race, Reproduction, and the Meaning of Liberty. New York: Vintage Books, 1997.

Schoen, Johanna. Choice \& Coercion: Birth Control, Sterilization, and Abortion in Public Health and Welfare. Chapel Hill \& London: The University of North Carolina Press, 2005.

Segal, Aaron with the assistance of Kent C. Earnhardt. Politics and Population in the Caribbean: Special Study No. 7. Rio Piedras, Puerto Rico: Institute of Caribbean Studies, University of Puerto Rico, 1969. 